\title{
Addition to the snake fauna of Pakistan: Mackinnon's Wolf Snake, Lycodon mackinnoni Wall, 1906
}

\author{
DANIEL JABLONSKI ${ }^{1 *}$, RAFAQAT MASROOR ${ }^{2}$, MUAZZAM ALI KHAN $^{3}$ \& MUHAMMAD ALTAF ${ }^{4}$ \\ ${ }^{1}$ Department of Zoology, Comenius University in Bratislava, Ilkovičova 6, Mlynská dolina, 84215 Bratislava, Slovakia \\ ${ }^{2}$ Pakistan Museum of Natural History, Garden Avenue, Shakarparian, 44000-Islamabad, Pakistan \\ ${ }^{3}$ Department of Zoology, Pir Mehr Ali Shan Arid Agriculture University, Rawalpindi, Pakistan \\ ${ }^{4}$ Department of Zoology, Women University of Azad Jammu and Kashmir, Bagh, Pakistan \\ *Corresponding author Email: daniel.jablonski@balcanica.cz
}

$\mathrm{P}$ akistan harbours around 71 snake species (Khan, 2006). A large snake fauna would be expected in Pakistan given that it covers a wide geographical area that includes three major zoogeographical regions and three large mountain ranges (Himalayan, Hindu Kush, and Karakoram). However, to date this snake diversity has probably been underestimated (Khan, 2006). Moreover, some of the species may represent species complexes with unclear taxonomy (e.g. genus Platyceps, Spalerosophis). Other species are expected to occur in Pakistan in cases where their known distributions reach close to the borders with neighbouring countries (especially India). A good example are species of the genus Lycodon Boie in Fitzinger, 1826 (wolf snakes). This genus represents about 50 Asian species but only three are currently known from the territory of Pakistan: L. aulicus (Linnaeus, 1758), L. striatus (Shaw, 1802) and L. travancoricus (Beddome, 1870). The first two are distributed in Pakistan from Sindh to Khyber Pakhtunkhwa Province whereas the third has been recorded only in one locality near Hyderabad, Sindh (Khan, 2006).

In this study, we provide the first record of the rare Mackinnon's Wolf Snake (L. mackinnoni Wall, 1906) from Azad Jammu and Kashmir (AJK), north-eastern Pakistan. This species was described by Wall (1906) from a single specimen collected by P. W. Mackinnon from the neighbourhood of Mussoorie, Uttar Pradesh, India (holotype BMNH 1946.1.13.81). Unusually for a Lycodon species the specimen was described as having no loreal scales although there were reservations about this due to the poor condition of specimen's head. Furthermore it is has been noted for Lycodon that "aberrations such as the union of the loreal scale with the prefrontal ..... are not unknown" and a subsequent description of L. mackinnoni has included loreal scales (Smith, 1943).

We undertook herpetofaunal surveys in the Bagh and Hattian Bala districts of AJK from November 2016 to April 2018. These involved active searching of different microhabitats in the two districts, e.g. in the vicinity of stream and ponds, agricultural fields, forests (pine, moist temperate and subtropical deciduous forest) and habitats near to human settlements. Local people were also questioned and some of our observations were based on low quality photos provided by them. The snakes recorded were identified using the keys in Lanza (1999) and Khan (2006). If possible, nine morphological and thirteen meristic characters, altitude, coordinates and valuable ecological data were recorded. Morphological measurements were made using digital callipers and geographic data by GPS (WGS 84). A single specimen (male) of L. mackinnoni was collected and preserved in $10 \%$

Table 1. An overview of all published and new distribution records of L. mackinnoni from Pakistan and India

\begin{tabular}{|c|c|c|c|c|c|c|c|}
\hline Number & Locality & $\mathbf{N}$ & $\mathbf{E}$ & $\begin{array}{l}\text { Elevation } \\
\text { (m) }\end{array}$ & Date & Observations & Source \\
\hline 1 & Hari Ghel, Bagh District, AJK & $33.9464^{\circ}$ & $73.7127^{\circ}$ & 830 & $\begin{array}{l}\text { April \& June } \\
\quad 2017\end{array}$ & 3 & This study \\
\hline 2 & Dhirkot, Bagh District, AJK & $34.0283^{\circ}$ & $73.5400^{\circ}$ & 1396 & May 2017 & 4 & This study \\
\hline 3 & Bagh city, Bagh District, AJK & $33.9904^{\circ}$ & $73.7759^{\circ}$ & 1127 & May 2018 & 3 & This study \\
\hline 4 & Hattian, Bala District, AJK & $34.1143^{\circ}$ & $73.8813^{\circ}$ & 1100 & May 2018 & 3 & This study \\
\hline \multicolumn{8}{|c|}{ Published records from India } \\
\hline 5 & $\begin{array}{l}\text { "Neighbourhood of Mussoorie", Uttar } \\
\text { Pradesh - type locality }\end{array}$ & $30.4595^{\circ}$ & $78.0715^{\circ}$ & $\sim 1860$ & - & - & Wall 1906 \\
\hline 6 & Mussoorie, Uttar Pradesh & $30.4595^{\circ}$ & $78.0715^{\circ}$ & $\sim 1900$ & - & - & Smith 1943 \\
\hline 7 & Alomar near Nainital, Uttarakhand & $29.5899^{\circ}$ & $79.6514^{\circ}$ & $\sim 1600$ & - & - & Smith 1943 \\
\hline 8 & Mukteshar near Nainital, Uttarakhand & $29.4619^{\circ}$ & $79.6538^{\circ}$ & $\sim 2000$ & - & - & Smith 1943 \\
\hline
\end{tabular}




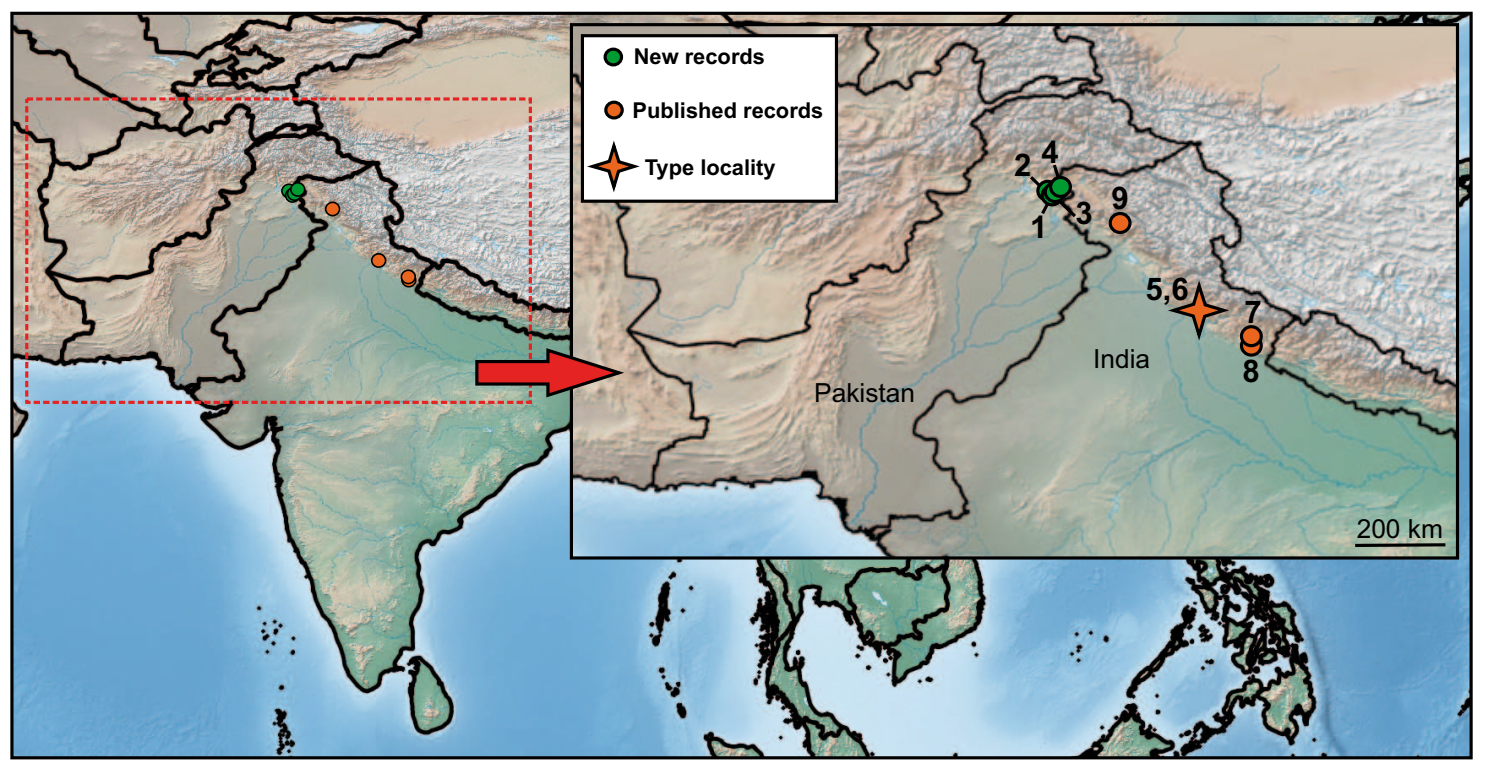

Figure 1. Published and new records of L. mackinnoni from India and Pakistan. Numbers on the map correspond with Table 1.

Table 2. A comparison with published measurements and scale counts of L. mackinnoni

\begin{tabular}{|c|c|c|c|}
\hline \multirow[t]{3}{*}{ Morphometry } & \multicolumn{3}{|c|}{ Measurements $(\mathrm{mm})$} \\
\hline & This study & Manhas et al. 2015 & Wall 1906 \\
\hline & $\begin{array}{c}\text { PMNH } 3916 \\
\text { adult, male } \\
\text { Hattian Bala, Azad Jammu and Kash- } \\
\text { mir, Pakistan }\end{array}$ & $\begin{array}{c}\text { Unvouchered } \\
\text { adult, ? } \\
\text { Nai, Doda district, Jammu and Kashmir, } \\
\text { India }\end{array}$ & $\begin{array}{c}\text { BMNH 1946.1.13.81 } \\
\text { adult, female } \\
\text { “Neighbourhood of Mussoorie”, Uttar } \\
\text { Pradesh. India } \\
\text { Type locality }\end{array}$ \\
\hline Snout-vent length & 350.0 & 354.0 & - \\
\hline Tail length & 88.2 & 80.0 & - \\
\hline Head length & 11.4 & 12.0 & - \\
\hline Head width & 5.0 & 3.0-5.0 (mouth to neck) & - \\
\hline Head height & 4.1 & - & - \\
\hline Eye diameter & 1.7 & 1.0 & - \\
\hline Distance b/w eyes & 3.7 & 4.0 & - \\
\hline $\begin{array}{l}\text { Ventral scales diam- } \\
\text { eter (at midbody) }\end{array}$ & 7.3 & 8.0 & - \\
\hline Total length & 438.2 & 435.0 & $\sim 355.0$ \\
\hline Meristics & \multicolumn{3}{|c|}{ Numbers } \\
\hline Supralabials & 8 & 8 & 8 \\
\hline Infralabials & 7 & 7 & $6 ?$ \\
\hline Supraocular & 1 & 2 & 1 \\
\hline Parietal & 2 & 2 & 2 \\
\hline Prefrontal & 2 & 2 & 2 \\
\hline Preocular & 1 & 1 & 1 \\
\hline Postocular & 2 & 1 & 2 \\
\hline Loreal & 1 & 1 & 0 \\
\hline Intranasal & 2 & 2 & 2 \\
\hline Temporal & $5(2+3)$ & $5(2+3)$ & $5(2+3)$ \\
\hline $\begin{array}{l}\text { Dorsal body scales } \\
\text { (one head length, mid- } \\
\text { body, one head length } \\
\text { before anus) }\end{array}$ & $17-17-15$ & $17-0-15$ & $17-17-15$ \\
\hline Ventrals & 180 & $193(163-187)$ & 192 \\
\hline Subcaudals (paired) & 57 (paired) & 53 & 54 (paired) \\
\hline
\end{tabular}




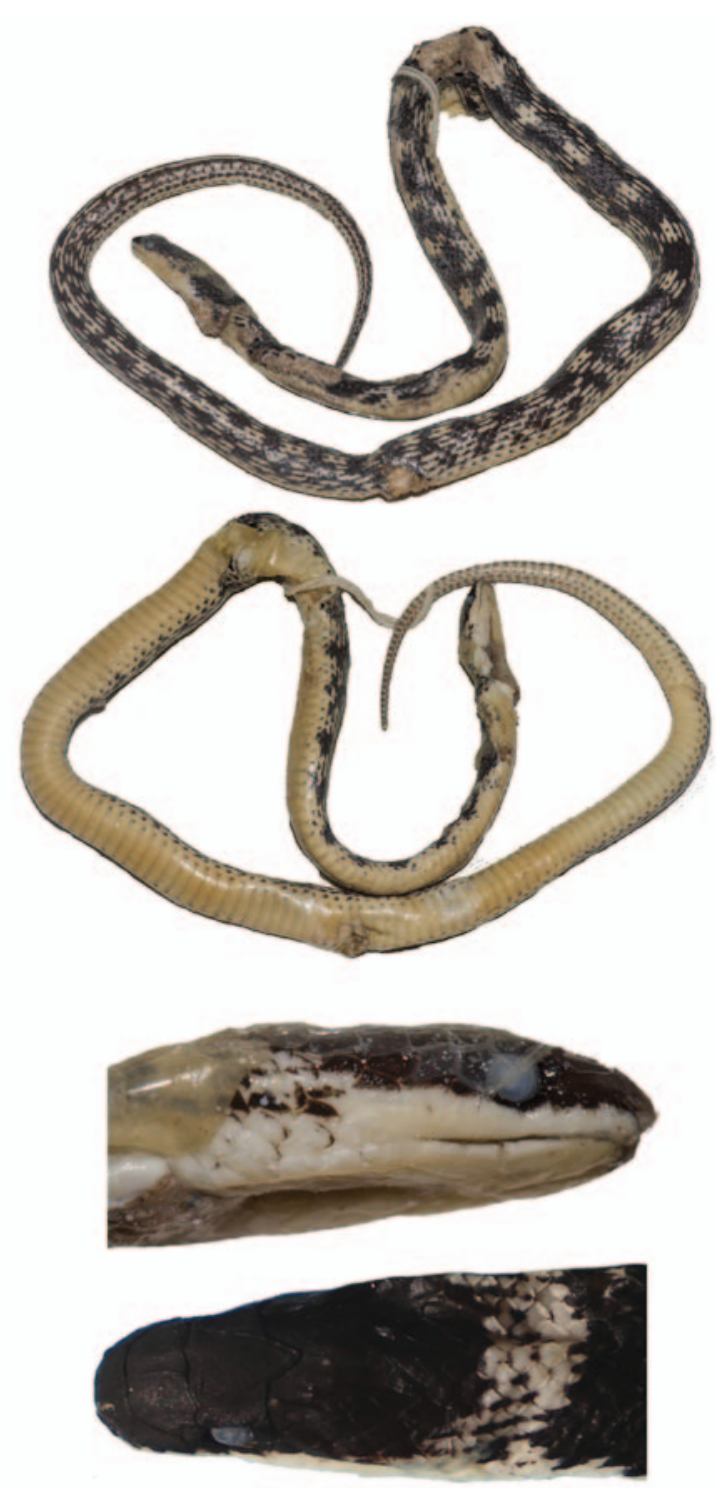

Figure 2. The preserved specimen PMNH 3916 of L. mackinnoni from Hattian Bala, Azad Jammu and Kashmir, Pakistan

formaldehyde while a tissue sample was placed in $96 \%$ ethanol. Both are stored in the Pakistan Museum of Natural History, Islamabad (voucher specimen) and Department of Zoology, Comenius University in Bratislava, Slovakia (tissue sample) under voucher numbers PMNH 3916 and 7944, respectively.

Lycodon mackinnoni was recorded from four geographically close localities of the Bagh and Hattian Bala districts with elevation ranging from 830 to $1396 \mathrm{~m}$ a.s.l. (Table 1, Fig. 1). The specimen we collected was a freshlykilled adult male from Hattian Bala. In addition, we recorded, but did not collect, 12 additional observations of adults from other localities (Hari Ghel, Dhirkot, and Bagh city). The snakes observed in Bagh district were found in humid localities with hot summers (about $37{ }^{\circ} \mathrm{C}$ ) and cool winters (about $4{ }^{\circ} \mathrm{C}$ ) but where snowfall is recorded only at higher elevations. Snakes from Hattian Bala district were from localities with warm summers but freezing cold winters. Morphometric and meristic data for the individual collected are shown in Table 2 where they are compared with published data.

Mackinnon's Wolf Snake is very rare and known only from a few localities in the western Himalayas (Wall, 1906; Smith, 1943; Fig. 1). This snake has only recently been recorded from Indian Jammu and Kashmir (Manhas et al., 2015), about $100 \mathrm{~km}$ from the border with Pakistani Punjub, a lowland province. Only five specimens are known from the published literature or museum collections and one of them (the holotype) has a damaged head. Thus any morphological data are important to present. Individuals observed by us did not differ in colouration, all having a black-yellow dorsal pattern which fades away in the posterior third but there were differences in subcaudal and ventral scales that may correspond with gender. It is worth noting that in our specimen the loreal scales were present otherwise all other characters fall within the original diagnostic and descriptive range for L. mackinnoni.

\section{ACKNOWLEDGEMENTS}

We thank M. Samar Hussain Khan, Mehwish Altaf, S. Irum Farooq, L. Safdar and R. Lal for their help in the field and two anonymous reviewers for their valuable suggestions that improved the first version of the manuscript. This work was supported by the Slovak Research and Development Agency under the contract no. APVV-15-0147.

\section{REFERENCES}

Khan, M.S. (2006). Amphibians and Reptiles of Pakistan. Krieger Publishing Company, Florida, USA. 328 pp.

Lanza, B. (1999). A new species of Lycodon from the Philippines, with a key to the genus (Reptilia Serpentes Colubridae). Tropical Zoology 12: 89-104.

Manhas, A., Wanganeo, R.R.N., Wanganeo, A. (2015). First record of Himalayan Wolf Snake (Lycodon mackinnoni Wall, 1906) in Doda District of Lower Himalayas, Jammu and Kashmir, India. World Research Journal Biology of Biological Sciences 1: 2-4

Smith, M.A. (1943). The Fauna of British India, Ceylon and Burma, Including the Whole of the Indo-Chinese Subregion. Reptilia and Amphibia. Volume III (Serpentes). Taylor and Francis, London, UK. 583 pp.

Wall, F. (1906). A new Himalayan snake (Lycodon mackinnoni). The Journal of the Bombay Natural History Society 17: 2930.

Accepted: 11 February 2019 